\title{
Effect of water depth and temperature on the productivity of a double slope solar still
}

\author{
T. A. Babalola, A. O. Boyo, R. O. Kesinro \\ Department of Physics, Lagos State University, Ojo, Lagos State, Nigeria
}

Email address:

olakesinro02@gmail.com (R. O. Kesinro),nikeboyo@yahoo.com (A. O. Boyo), babalolataoheed@yahoo.com (T. A. Babalola)

To cite this article:

T. A. Babalola, A. O. Boyo, R. O. Kesinro. Effect of Water Depth and Temperature on the Productivity of a Double Slope Solar Still. Journal of Energy and Natural Resources. Vol. 4, No. 1, 2015, pp. 1-4. doi: 10.11648/j.jenr.20150401.11

\begin{abstract}
Drinkable water is a basic necessity for humanity, and the increase in human population growth has led to water pollution to the surface and underground water reservoirs. In order to meet the increasing demand for potable water, researchers have developed various technologies to meet this target. Solar distillation is a technology suitable for producing distilled water from brackish water. This is achieved by the use of a solar still. A solar still is a simple solar device used in converting salt/brackish water into potable water. In this research, the productivity of water by a double slope solar still was determined by varying the water depth and surrounding temperature for nine days in the premises of Lagos State University, Ojo, Nigeria at $6.5^{\circ} \mathrm{N}, 3.35^{\circ} \mathrm{E}$. In this research embarked upon, it was observed that at a depth of $2.0 \mathrm{~cm}$ the maximum output of the solar still was obtained and a maximum efficiency of $25.3 \%$.
\end{abstract}

Keywords: Brackish Water, Productivity, Solar Still, Distillation

\section{Introduction}

The need for safe, clean drinking water is increasing rapidly due to rapid economic growth and increasing pressure on quality and quantity of water resources especially in developing countries. Water is readily available but it is brackish, salty and not safe for drinking. Emerging desalination technologies using renewable energy have made it possible to gain drinkable water as it can be cost effective.

In order to increase people's accessibility to potable water, some United Nations organizations such as the World Bank, World Health Organizations (WHO), United Nations Development Programme (UNDP) and United Nations Cultural and Educational Fund (UNICEF) have assisted various water projects for drinking. In the past, it was the arid regions that had brackish water that were known to be experiencing water shortage. However, the shortage has become phenomenal. To overcome this problem, there are various methods to produce fresh water from sea water, saline water or brackish water.

A solar still is a device that produces clean, drinkable water from dirty water using energy from the sun. Solar still is widely used in solar desalination. It has relatively low productivity but competitive to the other desalination methods for production of water due to its relatively low cost, simplicity in design and operation.

Several solar still designs have been proposed and many of them have found significant applications throughout the world. Solar desalination systems have low operating and maintenance costs and require large installation areas and high initial investments. There are two different types of solar still, those are; active solar still and passive solar still. Figure 1 indicates active type solar still; which contains the mechanical components like pump, valve etc. Figure 2 shows the passive type solar still; which don't require any mechanical components. Among active and passive solar stills passive solar still get more attractive comparing with active solar still. Because passive type solar still don't have moving elements, so no need of power consumption and no wear and tear problems.

By making necessary modifications to improve rate of heat transfer we can fetch maximum output from solar desalination. Reference [1] evaluated the distillate yield for a double slope laboratory still under controlled conditions for basin water and collector temperature within typical operating range. Reference [2] explored the current desalination technologies and their respective energy demands in Gulf Cooperation Council (GCC) countries with 
different alternatives to reduce energy consumption and analyze the present and the future prospective of water production rates and trends as well as the corresponding energy consumptions. Reference [3] developed an equation to predict the daily productivity of a single-sloped solar still. The developed equation relates the dependent and independent variables which control the daily productivity. Reference [4] was study of solar still using nanofluids and they found that using nanofluids in a solar still can increase the productivity of solar still. The effect of adding carbon nanotubes to the water inside a single basin solar still efficiency increases by $50 \%$. Also, [5] studied the effects of orientation and depth of water in the basin of the still on the productivity of a double slope solar still and compare the same with that of a single slope solar still. Reference [6] conducted a study on solar distillation system by fuzzy sets. The study reveals that wind speed, ambient temperature, solar intensity, sprinkler, coupled collector, solar concentration, water depth etc affect on yield of solar still. Referene [7] developed single slope solar still with reflecting mirrors fixed on interior sides was coupled with a flat plate collector. He found that the daily productivity increased $(5310 \mathrm{ml}), 36 \%$ more than normal still operation $(2240 \mathrm{ml})$ due to coupling with solar collector. He also observed that increased in basin water depth decreases the productivity and still productivity was proportional to the solar radiation intensity. Reference [8] compared the effect of desert climatic conditions on performance of a simple solar still with a similar one coupled to a flat plate collector. They tested whole day under clear sky conditions with different depth levels $(2.5$ to $3.5 \mathrm{~cm}$.) of brackish water. The still productivity in summer varied from 4.01 to $4.341 / \mathrm{m} 2 / \mathrm{d}$ for simple basin and 8.02 to $8.07 \mathrm{l} / \mathrm{m} 2 / \mathrm{d}$ for the coupled one.

In this research work a double slope solar still was fabricated and distillate output was collected at different depths and temperature under normal climatic conditions in Lagos State University, Nigeria.

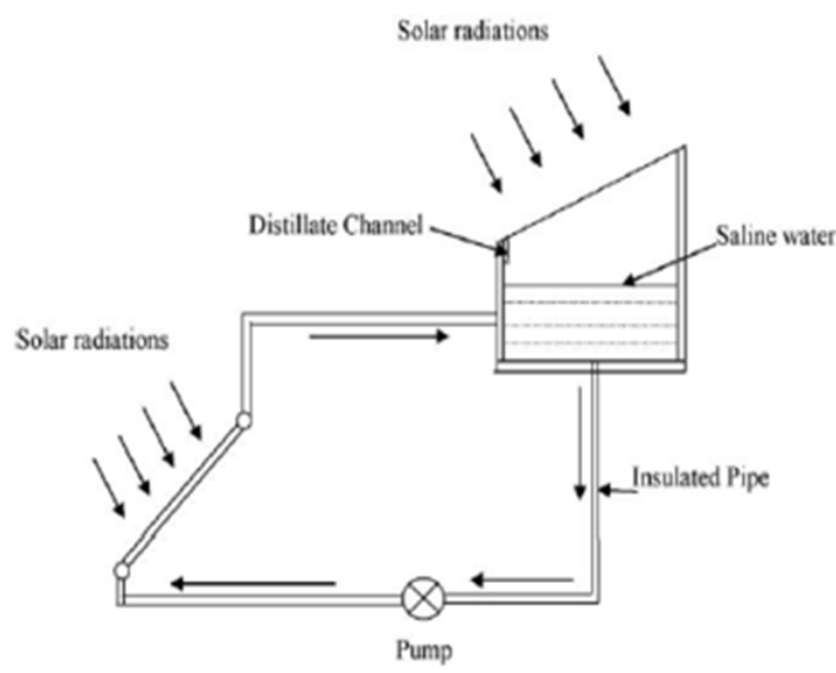

Figure 1. Active type solar still

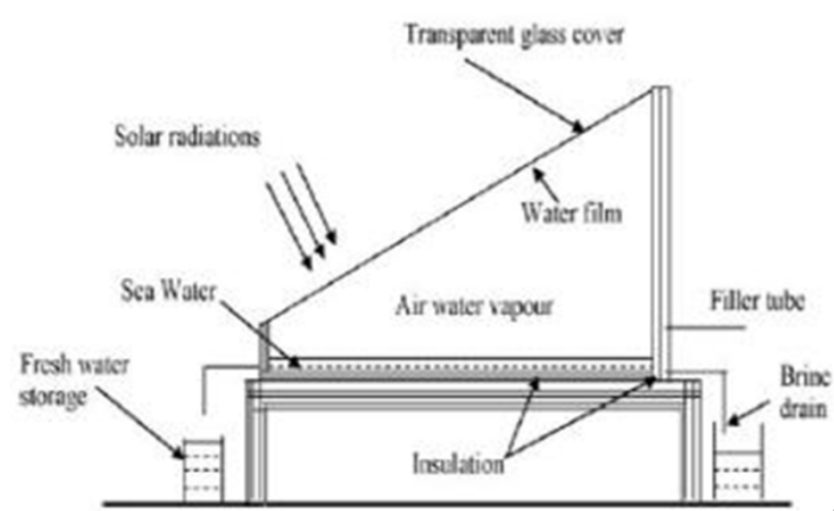

Figure 2. Passive type solar still

\section{Methodology}

The double slope basin-type solar still, constructed here, basically consists of an aluminum basin of dimensions $1.20 \mathrm{~m}$ by $0.72 \mathrm{~m}$ by $0.50 \mathrm{~m}$, placed in a wooden casing of dimensions $140 \mathrm{~cm}$ by $74 \mathrm{~cm}$ by $0.5 \mathrm{~cm}$; and roofed with tempered-glass cover plates of tilt angle $50^{\circ}$ (to the horizontal).

The solar still rests on a robust plastic stand of approximate height of $45 \mathrm{~cm}$ and top surface area roughly the same as that of the base of the casing. Fig. 1 shows the diagram of the solar still. The level of the water in the basin was maintained by the use of a floater and the average mean ambient temperature for the day was obtained from the laboratory. The experimental setup for the research is as follows;

- The principal energy exchange mechanism in basin of solar still. A large part of solar radiation, direct and diffused, falling on still is absorbed in the blackened basin.

- The sensible heat absorbed by water is used to evaporate it and transferred to glass as vapour.

- The required output from the still is the condensed water on the bottom surfaces of the glass cover.

- The condensation is higher when condensing heat transfer from the basin of water is high.

- To maximize amount of water condensed.

A basin of solar still has a thin layer of water, a transparent glass cover that covers the basin and channel for collecting the distillate water from solar still. The glass transmits the sunrays through it and saline water in the basin or solar still is heated by solar radiation which passes through the glass cover and absorbed by the bottom of the solar still. In a solar still, the temperature difference between the water and glass cover is the driving force of the pure water yield. It influences the rate of evaporation from the surface of the water within the basin flowing towards condensing cover. Vapour flows upwards from the hot water and condense. This condensate water is collected through a channel. 


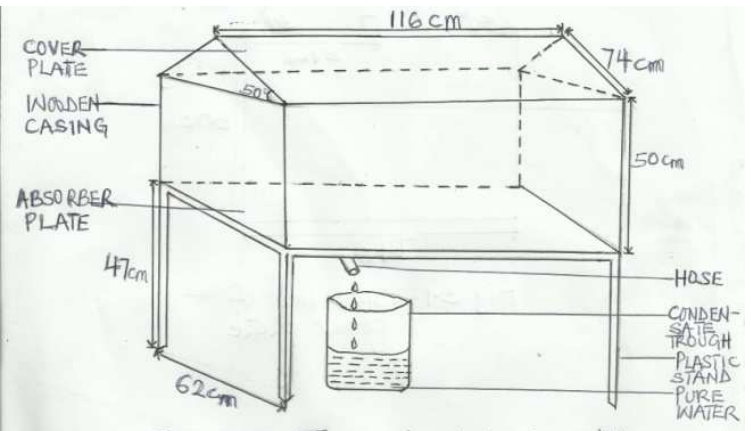

Fia. 3.2 - The conatructed solaur still

Figure 3. Schematics of the double slope still

Table 1. Technical specification of solar still

\begin{tabular}{ll}
\hline Specification & Dimensions \\
\hline Aluminium basin & $1.20 \mathrm{~m} * 0.72 \mathrm{~m} * 0.50 \mathrm{~m}$ \\
Wooden casing & $1.40 \mathrm{~m} * 0.74 \mathrm{~m} * 0.50 \mathrm{~m}$ \\
Tilt angle of cover glass & $50^{\circ}$ \\
Width of cover glass & $0.58 \mathrm{~m}$ \\
Material of cover glass & Tempered glass \\
\hline
\end{tabular}

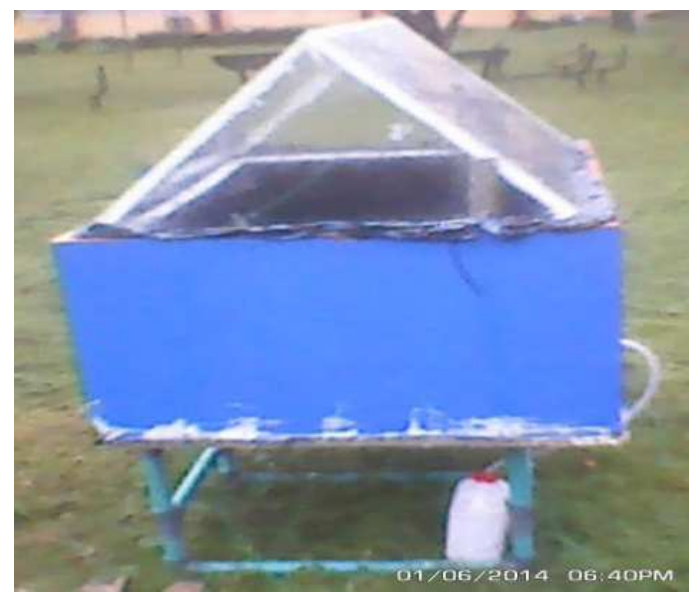

Figure 4. Double slope solar still

\section{Result and Discussion}

In this paper, the system is operated within 7 days with moderate and low sunshine of Ojo, Lagos state, Nigeria. The main target of this paper is to determine the effect of ambient temperature and depth of the brackish water on the output of the solar still. It was observed that maximum solar still output was recorded at the lowest water depth used $(2.0 \mathrm{~cm})$. The graph of productivity against depth shown in graph 1 also shows that the output decreased non-linearly with increasing water depth, in concord with the findings of some earlier researchers like [9] and [10]. Consequently, the maximum instantaneous or daily efficiency $\mathrm{y}$ of the solar still is calculated from the data of distillate obtained at depth $2.0 \mathrm{~cm}$, using the equation

$$
\mathrm{y}=\mathrm{Q} / \mathrm{H}_{\mathrm{T}}
$$

Where $\mathrm{Q}=$ amount of solar energy utilized by the still and $\mathrm{H}_{\mathrm{T}}=$ Solar insolation on horizontal surface.

Therefore, the maximum average daily efficiency of the still is $25.3 \%$. This is rather low and confirms the remark of [11] that solar still is not popular even in the remote arid areas because of its low productivity.

Also, the ambient temperature was also used to determine the productivity of the solar still and it was observed that the highest output was obtained at the maximum ambient temperature of $29.5^{\circ} \mathrm{C}$ as shown in graph 2. This fairly underscores the fact the solar still productivity also depends on temperature.

Table 2. ambient temperature, depth and productivity

\begin{tabular}{lllll}
\hline Days & $\begin{array}{l}\text { Average } \\
\text { Temp. }\left({ }^{\mathbf{o}} \mathbf{C}\right)\end{array}$ & Depth $(\mathbf{c m})$ & $\begin{array}{l}\text { Productivity } \\
\left(\mathbf{m L} / \mathbf{m}^{\mathbf{2}} \mathbf{d a y}\right)\end{array}$ & $\begin{array}{l}\text { Max. Solar } \\
\text { energy }(\mathbf{J})\end{array}$ \\
\hline 1 & 29.5 & 2 & 298 & 1002 \\
2 & 28.0 & 3 & 268 & 844 \\
3 & 28.0 & 4 & 255 & 872 \\
4 & 27.0 & 5 & 242 & 733 \\
5 & 26.0 & 6 & 236 & 884 \\
6 & 27.5 & 7 & 228 & 953 \\
7 & 27.5 & 8 & 225 & 888 \\
\hline
\end{tabular}

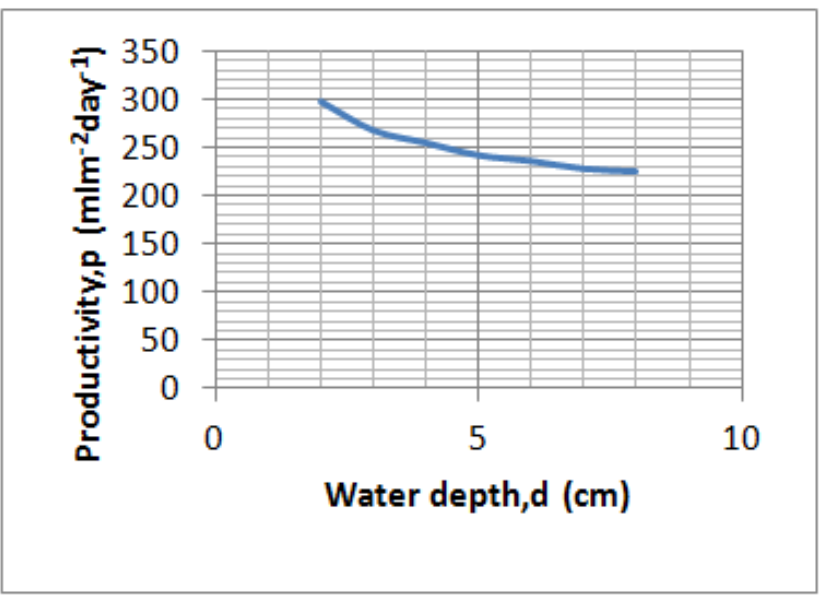

Graph 1. Graph of productivity against depth.

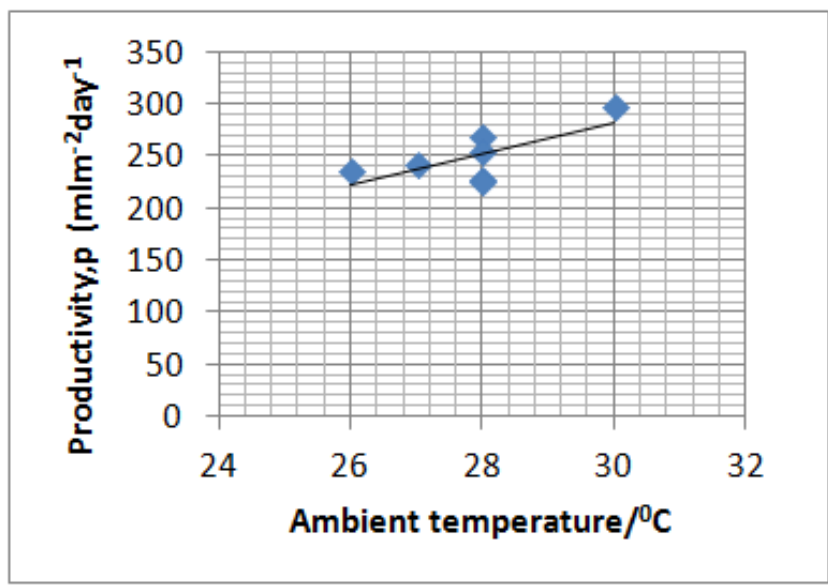

Graph 2. Graph of productivity against ambient temperature.

\section{Conclusion}

On the basis of this research the effect of water depth and ambient temperature on the productivity of the solar still was observed. It can be concluded from the paper that the 
increase in depth of the brackish water will result in low distillate output and increase in ambient temperature could result in increasing output. Also, more research has to be embarked upon to determine ways and materials to be used to increase the output of solar stills and make them more efficient.

\section{References}

[1] Rubio, E., M.A. Porta, J.L. Fernandez, Cavity geometry influence on mass flow rate for single and double slope solar stills, Applied Thermal Engineering 20 (2000) 1105-11, doi:10.1016/S1359-4311(99)00085-

[2] H. Fath, A. Sadik and T. Mezher, Present and Future Trend in the Production and Energy Consumption of Desalinated Water in GCC Countries, Int. J. of Thermal \& Environmental Engineering Volume 5, No. 2 (2013) 155-165, doi: $10.5383 /$ ijtee. 05.02 .00

[3] A.S. Nafey, M. Abdelkader, A. Abdelmotalip and A.A. Mabrouk, Solar still productivity enhancement, Energy conversion and management,42 (2001) 1401-08, doi:10.1016/S0196-8904(00)00107-2

[4] Gnanadason M K, Kumar P S, Rajakumar S and Yousuf M H $\mathrm{S}$ (2011), "Effect of nanofluids in a vacuum single basin solar still”, IJAERS, 1, pp: 171-177, 2011.
[5] M.R. Rajamanickam, A. Ragupathy, Influence of Water Depth on Internal Heat and Mass Transfer in a double slope solar still, Energy procedia, 14 (2012) 1701-08, doi:10.1016/j.egypro.2011.12.887

[6] Mamlook R and Badran 0,(2007) Fuzzy sets implementation for the evaluation of factors affecting solar still production, Desalination, 203, pp. 394-402.

[7] Badran 0.0. and Al- Tahaineh H.A.,(2005) The effect of coupling a flat-plate collector on the solar still productivity, Desalination, 183, pp. 137-142.

[8] Boukar M. and Harmim A.,(2001) Effect of climatic conditions on the performance of a simple basin solar still: a comparative study, Desalination, 137,pp. 15-22.

[9] XAbdul Jabbar, N. Khalifa \& Ahmad, M. Hamood (2009). On the Effect of Water Depth on the Performance of Basin-type Solar Stills. Solar Energy 83: 1312-1321.

[10] Garg, H.P., Mann, H.S., 1976. Effect of climatic, operational and design parameters on the year round performance of a single slop and double slop solar still under Indian arid zone conditions. Solar Energy 18, 159-164..

[11] Kalidasa, K., and Srithar, K. (2012). Performance Study on Basin-Type Double-Slope Solar Still With Different Wick Materials and Minimum Mass of Water. Renewable Energy. 36(2): 612-620 